\title{
Risk Assessment on Integrated Information Smart Service using COBIT 5 Framework
}

\author{
Eko Bambang Nuralim \\ Department of Information System \\ Universitas Ahmad Dahlan \\ Yogyakarta of Indonesia
}

\author{
Imam Riadi \\ Department of Information System \\ Universitas Ahmad Dahlan \\ Yogyakarta of Indonesia
}

\begin{abstract}
The population administration information system is intended for information technology-based information system services that are used for structuring the administration of the population sector and controlling administrative services, one of which can be used with the DISDUKCAPIapplication Smart Bantul. The framework is COBIT 5used by researchers in analyzing risk assessments on organizational services in obtaining risks that interfere with data assets and organizational information assets by using a mitigation approach to possible risks that occur by providing recommendations. The COBIT 5 framework with the EDM03 (process domainsEnsure Risk Optimization) and APO12 (Risk Management)and the Likert scale for calculating questionnaires are used in risk management assessments in research that aims to determine the level of IT risk management capability with the Process Assessment Model COBIT(PAM) methodology 5 which consists of the stages Initiation, Planning the Assessment, Briefing, Data Collection, Data Validation, Process Attribute Level and Reporting the Result. Based on the results of the study, the level of risk management and risk optimization EDM03 (Ensure Risk Optimization) and APO12 (Risk Management) is currently at level 3 (Established Process) with a Gap value of 1 level and the capability indicators obtained in the study. serve as the basis for making recommendations. This research has been carried out well following the expected research objectives.
\end{abstract}

\section{Keywords}

Risk Management, Capability Level, Gap, RACI Chart, Skala Likert.

\section{INTRODUCTION}

The development of modern IT is increasingly rapid, so that every organization, both government and private, applies the existence of technology in carrying out the operations of a business. All organizational activities requireinformation, thereforeinformation becomes a very important part to support the process of taking action decisions with the existence of an information system, thus information technology services can provide better and effective services in providing information data.

The Department of Population and Civil Registration of Bantul Regency which is located in Complex II of Bantul Regency Government Offices, Jl. East Ring, Manding, Rice Fields, Trirenggo, Kec.Bantul, Bantul, Special Region of Yogyakarta 55714 has implemented the development of Information Technology. The service applied is in the form of an application service, namely DISDUKCAPIL Smart Bantul which can assist the community in managing administrative and population data, which at first the people made administrative submissions manually by visiting the Population and Civil Registration Office and have applied services that can be done online.

COBIT 5 provides a comprehensive framework that can help companies achieve IT governance and enterprise management goals. The author uses the Evaluate, Direct, and Monitor (EDM) and Align, Plan andOrganise(APO) domains by focusing on the EDM03 (Ensure Risk Optimization) and APO12 sections Manage Risk. The application of risk management is used to identify and map the quality of risks that will occur, whether they have a positive or negative impact, so it is necessary to carry out a risk assessment analysis so that later it is expected to provide solutions related to potential risks that will arise.

\section{STUDY LITERATURE}

\subsection{Definition of Evaluation}

Evaluation is part of the management system, namely planning, organization, implementation, monitoring, and evaluation. According to, evaluation is a planned activity to determine the state of an object by using instruments and the results are compared with benchmarks to obtain conclusions. According to evaluation is a process of determining the results that have been achieved by several activities that are planned to support the achievement of goals.[15].

In learning activities, a teacher must master some knowledge related to educational assessment, including Able to choose appropriate assessment procedures to make learning decisions, Able to develop appropriate assessment procedures to make learning decisions, Able to implement, score, and interpret the results of the assessment that have been made, Able to use the results of the assessment to make decisions in the field of education, Able to develop valid assessment procedures and use assessment information, and Able to communicate the results of the assessment[24].

"Evaluation is a systematic process determining the extent to which instructional objectives are achieved by pupils" [25]. The sentence explains that assessment is a process of gathering information and making decisions based on that information. In the process of gathering information, of course, not all information can be used to make a decision. Information that is relevant to what is being assessed will make it easier to carry out an assessment in learning activities.

\subsection{Definition of Risk}

A risk is an adverse event. In the investment field, the risk is defined as the possibility that the results obtained deviate from what is expected[20]. 


\subsection{Definiton of ITRisk Management}

Information technology risk management is an organization's ability to reduce IT risks that might hinder the achievement of organizational goals related to the use of IT itself. [18]

\subsection{COBIT5}

COBIT 5 (Control Objective for Information and Related Technology) is a set of guidelines and documentation that serves to assist stakeholders or users in connecting between the business control model and the IT control model. COBIT 5 is an amalgamation of the latest thinking in corporate governance and management techniques. COBIT 5 in-depth can assist companies in creating optimal value from IT, namely between realizing benefits and optimizing the level of risk with the use of resources. COBIT was developed to implement IT Governance of Enterprise. The latest version released by the IT Governance Institute is known as COBIT 5. COBIT 5 was formed by integrating the Risk IT framework, VAL IT 2.0, and COBIT 4.1. In the 2012 ISACA journal, COBIT 5 (Control Objectives for Information and Related Technology) explained that in general it has 5 basic principles and the following are 5 basic principles in COBIT 5[14]:

a. The first principle (Meeting Stakeholder Needs) is to be able to meet the needs (stakeholders) to maintain balance and optimize risk because each company has a different vision and mission.

b. The second principle is Covering the Enterprise end-toend), which is covering the End-to-End enterprise considering all IT governance and management enablers for the company or optimizing the IT governance of each company.

c. The third principle (Applying a Single, Integrated Framework) is related to standards that usually guide some IT activities.

d. The fourth principle (Enabling a Holistic Approach) is governance and management that effective and efficient corporate requires a comprehensive approach, which considers interacting components. COBIT 5 defines a set of enablers to support the governance comprehensive implementation of corporate IT systems and management.

e. The fifth principle (Separating Governance from Management) is to provide a clear separation between management and governance. They cover different activities, require different organizational structures, and serve different purposes.

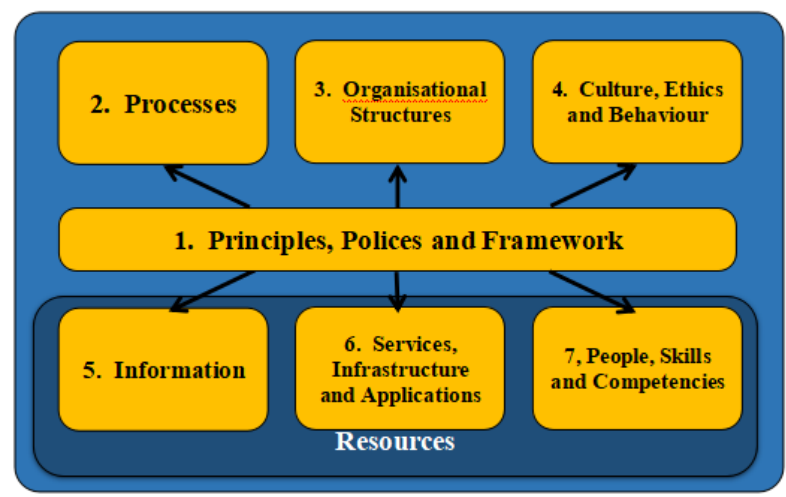

Figure 1: enablers contained in COBIT 5

In addition to the 5 principles described above, there are 7 enablers contained in COBIT 5, here are the explanations for these 7 supporters in Figure 1[14]. a. Policy principles and frameworks are the enablers first of COBIT 5, these enablers function to formulate needs and behaviors (stakeholders) into practical guidelines that will be used in the company's operational activities in the IT sector.

b. The process as an enabler has a role to provide details about a series of activities and practical activities carried out to achieve the goals of the company.

c. Organizational structure is the key to decision-making in the organization. The decisions made must also meet the needs and objectives of all (stakeholders). So that the entity is responsible for the decisions and policies made by the company.

d. Every company has its own culture, ethics, and habits, these habits can occur due to many factors and can also be personal or organizational. Some values and corporate goals can only be achieved with good corporate and habits, therefore a standard is needed to provide an assessment of culture, custom, and ethics.

e. Information is a very important factor for business activities within a company because the information is a requirement for making movements within the company such as making decisions and solving problems.

f. Infrastructure and applications including infrastructure, technology and applications that provide services are objects and objects become drivers in COBIT 5. These objects provide services to technology and information processes for companies.

g. Skills and competencies relate to people and are needed to carry out all activities successfully and make appropriate decisions and take corrective actions.

In addition, COBIT 5 also adjusts the existing best practices such as ITIL V3, TOGAF, and relevant standards from ISO. ISACA (2012) explains that seven stages must be carried out according to the COBIT 5 implementation cycle: [13].

a. Initiate Program, is process of identifying change triggers such as important issues, conditions, software implementation, performance, and organizational goals that can provide the impetus for change.

b. Define Problems and Opportunities, is process of aligning the objectives of IT implementation with organizational risks and strategies, and prioritizing the objectives of IT implementation.

c. Define Road Map, is process of setting targets to increase improvement efforts and followed by a gap analysis to determine several potential solutions that exist in a company.

d. Plan Program, is process of planning solutions that are considered feasible to run in an organization or company.

e. Execute Plan, is process of implementing suggested solutions into daily activities and monitoring to ensure that business alignment can be achieved and performance can be measured.

f. Realize Benefits, is continuous transition process by implementing governance practices and monitoring progress by mapping them on a matrix based on performance and benefits to be obtained.

Review Effectiveness, the process of evaluating success in general, then identifying any improvement needs regularly to improve governance or management practices.

COBIT 5 has two processes, namely: discussing Information Technology (IT) risk management, namely EDM03 and APO12[13]. 
a. EDM03 (Ensure Risk Optimization) Aims to ensure the level of risk and acceptable tolerance level for the company is well understood, articulated, and communicated, as well as ensuring whether IT-related risks have been identified and managed properly. The EDM03 process consists of EDM03.01 (Evaluate Risk Management), EDM03.02 (Direct Risk Management), and EDM03.03 (Monitor Risk Management).

b. APO12 (Manage Risk) Aims to identify, assess and reduce IT-related risks so as not to exceed the tolerance limits set by the organization. And integrate IT risk management with enterprise risk management (ERM). This process consists of APO12.01 (Collect Data), APO12.02 (Analyse Risk), APO12.03 (Maintain A Risk Profile), APO12.04 (Articulate Risk), APO12.05 (Define a Risk Management Action Portfolio), and APO12.06 (Responded to Risk).

\subsection{Capability Level}

The measurement criteria based on the measurementpoints contained in the COBIT 5 self-assessment template, the rating scale that will be used in the measurement at each level which will later be used to meet the value at each point as shown in the following Table 1:[14].

Table 1. Capability Level Result Recapitulation

\begin{tabular}{|c|c|c|}
\hline Code & Description & Range \\
\hline N & Not achieved & $0-15 \%$ \\
\hline P & Partially achieved & $>15-50 \%$ \\
\hline L & Largely achieved & $>50-85 \%$ \\
\hline F & Fully achieved & $>85-100 \%$ \\
\hline
\end{tabular}

a. N (Not achieved/ not achieved), In this category, there is no or little evidence of the achievement of the process attributes. The range of values achieved in this category ranges from $0-15 \%$.

b. P (Partially achieved), In this category, there is some evidence regarding the approach and several attribute achievements for the process. The range of scores achieved in this category ranges from $15-50 \%$.

c. L (Largely achieved), in this category there is evidence of a systematic approach, and significant achievements in the process, although there may still be insignificant weaknesses. The range of values achieved in this category ranges from $50-85 \%$.

d. F (Fully Achieved), In this category there is evidence of a systematic and complete approach and full achievement of the attributes of the process. There are no weaknesses related to the attributes of the process. The range of scores achieved in this category ranges from $85-100 \%$.

\subsection{Likert Skala Scale Calculation Method}

The Likert scale is used to measure attitudes, opinions, and perceptions of a person or group of people about social phenomena, this social phenomenon has been specifically defined by researchers and hereinafter referred to as variables research, determines the value and level of capability of the EDM03 and APO12 processes [21].

a. Calculating the Recapitulation of Questionnaire with C: Capability Level (in the form of a percentage for each answer choice $\mathrm{a}, \mathrm{b}, \mathrm{c}, \mathrm{d}$, e or $\mathrm{f}$ in each activity), $\mathrm{H}$ : The number of answers to the Capability Level questionnaire for each answer choice $\mathrm{a}, \mathrm{b}, \mathrm{c}, \mathrm{d}$, e, or $\mathrm{f}$ in each activity, JR: Number of Respondents/Resources.

b. Calculating Capability Scores and Levels with NK: Capability value in IT process, LP: Level percentage
(Percentage level in each distribution of capability level questionnaire answers) and Nk: The capability value listed in the answer mapping table,value, and capability level.

The information technology risk management method is a framework designed to address the various risks associated with the use of information technology. Here are some references that will form the basis for creating the method. These methods include COBIT, OCTAVE, ITIL, NIST, and others.

\section{METHODOLOGY}

\subsection{Research Stages}

This research will use primary data and secondary data. Primary data were obtained through interviews, observations, and questionnaires distributed to the DISDUKCAPIL Smart Bantul, Yogyakarta. While secondary data is obtained from the internet, from institutions or agencies, and also obtained from trusted articles to assist in the process of collecting data. In this research, there are stages in the work of the research to make it more focused and systematic. The following are the stages of the research as shown in Figure 2: [13].

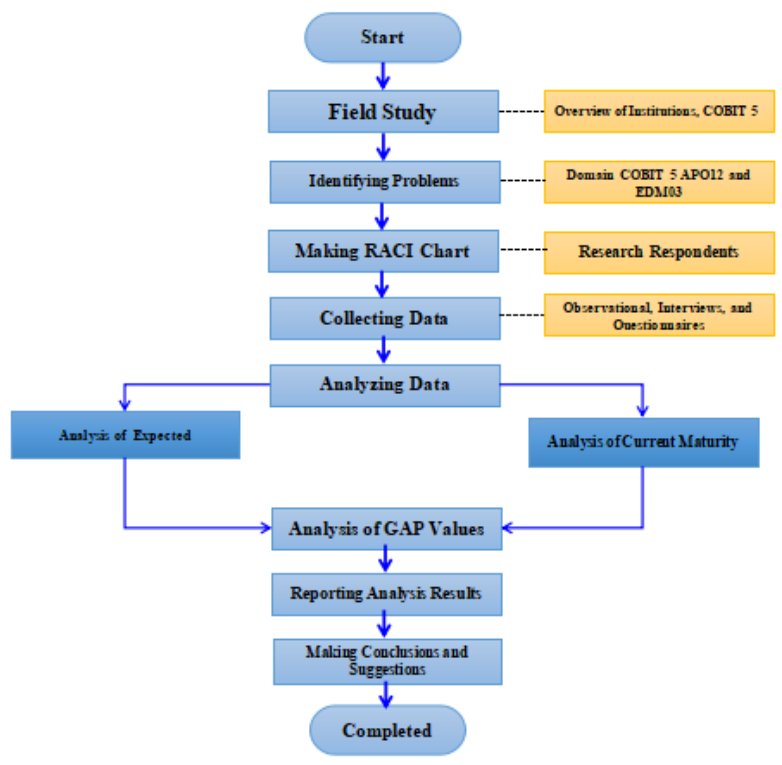

Figure2: Stages of Research

The research stage includes 6 steps in outline as follows:

1. The first stage the researcher will start the research by conducting a literature study as an initial stage, the literature study is carried out by collecting references from both journals and books. There are 6 journals cited, of course, journals used in research in the last 3 years, and 1 book on COBIT 5.

2. The second stage identifies the problem, at this stage the researcher makes direct observations in Human Resources in Higher Education to get the results of the problem. Synchronizing the problem with the method taken, namely COBIT 5 and position mapping using the RACI Chart method.

3. The third stage is collecting data. Data collection techniques using the media Questionnaire, Observation, and Interview.

4. The fourth stage performs data analysis. First, the researcher will assess the maturity value of the current capability level by processing the questionnaire data, then the researcher will assess the desired capability 
level maturity value, and the last time the researcher conducts a gap assessment.

5. The fifth stage, the researcher will make recommendations following each domain that has a gap value, the follow-up if the recommendations are implemented the organization will have the advantage of being able to reach the desired level. Recommendations will then be reported to human resources in universities as input to increase the desired level.

The sixth stage the researcher will share suggestions and conclusions in conducting research based on known results.

\subsection{Data Analysis Method}

The method used to identify capability levels, find gaps, and determine recommendations, researchers use Assessment Process Activities based on the COBIT 5 framework which consists of:[14].

1. Initiation, this stage describes the driving force in the organization. Identify current change drivers and change needs at the executive management level. The goal is to gain an understanding of the current organization.

2. Planning the Assessment, the second stage is to carry out an assessment plan that aims to obtain the results of the evaluation of the capability level assessment. This stage performs an assessment plan that aims to obtain the required data on EDM03 (Ensure Risk Optimization) and APO12 (Manage Risk).

3. Briefing, in this third stage the researcher provides direction to the respondents in the RACI diagram so that they understand the input, process, and output in the organizational unit and explain the research schedule to be carried out both direct and indirect communication to determine the schedule for filling out the questionnaire, notification of obstacles that encountered in making the assessment.

4. Data Collection, the fourth stage is collecting data from the findings contained in the agency/organization which aims to obtain evidence of evaluation assessment on process activities that have been carried out.

5. Data Validation, the fifth stage is data validation which aims to find out the results of the questionnaire calculation to get an evaluation of the assessment capability level.

6. Process Attribute Level, the sixth stage is the process of assigning a level to the attributes that exist in each indicator, which aims to show the capability level results from the results of the questionnaire calculations in the previous stages and perform gap analysis at the next stage.

7. Reporting the Result, seventh stage at this stage the researcher reports the results of the evaluation that has been done by providing a report on the results of risk identification and gap analysis which can be used as a company to achieve the expected level. Mitigation measures and proposed improvements are directed so that the company can reach the expected maturity level.

\subsection{Data Collection Method}

In this study, the author will use quantitative research methods. The reason in this study using quantitative methods is because in data processing this research produces values in the form of numbers and calculation analysis using statistics. Then the population or sample is studied, the data collection stage uses research instruments, statistical data analysis aims to test the established hypothesis. The research process is deductive, which aims to answer the problem formulation using concepts or theories. Hypotheses were tested through field data collection. The characteristics of quantitative methods have a specific, detailed design and have standard research steps [15].

The following are the stages in data collection:

1. Observation, is data collection method is complex because it involves various factors in its implementation. In this study, observations were made by studying or understanding the Smart Bantul DISDUKCAPIL Service Information System at the Bantul Population and Civil Registration Service.

2. Literature Study, Methods of data collection that are not addressed directly to the research subject. Collecting data and information from sources related to the research topic. Literature study data was obtained from reliable sources such as books, theses, journals, or ebook obtained from the sources of the Garuda portal, Sinta, Google, and also Scholar Iee explore.

3. Interview, Data collection techniques are carried out through face-to-face and direct questions and answers between researchers and resource persons. This interview was conducted to obtain accurate information from trusted sources. Interviews were conducted in this study with resource persons, namely Mrs. Emmy Nikmawati, SH (Head of PIAK and Data Utilization) related knowledge about the Smart Bantul DISDUKCAPIL Service Information System at the Population and Civil Registration Office of Bantul Regency.

4. Questionnaire, is data collection method is carried out by giving the respondents a set of questions or written statements to be answered. Questionnaires are made based on the sub-domains of each APO12 and EDM03 activity with guidelines in the book Framework COBIT 5 published by ISACA. The distribution of questionnaires was carried out by giving questionnaires in hardcopy or soft files along with explanations given to the Department of Population and Civil Registration of Bantul Regency.

\subsection{Risk Assessment Method}

The risk assessment method used in this study uses the COBIT 5 framework by focusing on 2 domains, namely APO12 (manage risk) and EDM03 (Ensure Risk Optimization). The assessment process in APO12 (manage risk) focuses more on identifying, assessing, and mitigating IT-related risks within the tolerance level determined by agency management. Meanwhile, the assessment process in EDM03 (Ensure Risk Optimization) ensures risk optimization, namely to ensure that agency risks can be understood, articulated and communicated to the agency's values related to the use of IT that are identified and managed properly.

\section{RESULTS AND DISCUSSION}

Determining research respondents using the RACI Chart and considering and adjusting the tasks and functions of the integrated service information system at the Population and Civil Registration Office of Bantul Regency to the Roles and Organizational Structures in the COBIT RACI Chart 5. Researchers also selected them by collecting data as a reference for selecting respondents they felt according to the institution's current state. 


\subsection{Analysis Results}

Determination of the level of capability on:

The following is the determination of the EDM03 capability level based on the calculation results of the capability values contained in each sub process, as shown in the following Table 2:

Table 2. Determination of the EDM03 capabilities

\begin{tabular}{|c|c|c|c|c|c|}
\hline \multirow{2}{*}{ No } & \multirow{2}{*}{$\begin{array}{c}\text { Sub- } \\
\text { Domain }\end{array}$} & \multicolumn{2}{|c|}{ Value } & \multicolumn{2}{c|}{ Capability } \\
\cline { 3 - 6 } & As is & To be & As is & To be \\
\hline 1 & EDM03.01 & 3,6 & 4,57 & 4 & 5 \\
\hline 2 & EDM03.02 & 3,17 & 4,37 & 3 & 4 \\
\hline \multicolumn{2}{|c|}{ AVG } & 3,39 & 4,47 & 3,5 & 4,5 \\
\hline
\end{tabular}

Based on the table above, it is known that the EDM03.01 process capability level is currently at level 4 with a capability value of 3.6, in the EDM03.02 process the capability level is currently at level 3 with a capability value of 3.17 , in the EDM03.03 process capability level. currently at level 3 with a capability value of 3.2. From the three sub-processes, it is known that the capability value for the EDM03 process is 3.32, as shown in Figure 3:

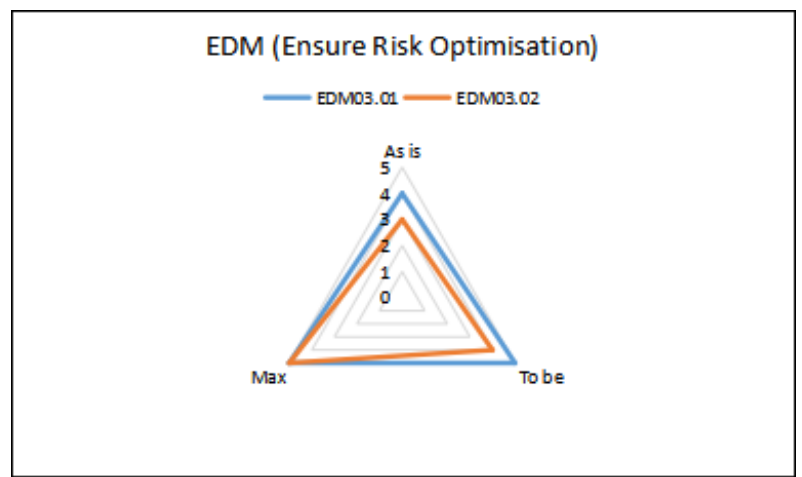

Figure3: Graph EDM03 of Capability value

Based on the graph above, it is known that the current condition in the EDM03 (Ensure Risk Optimization) process is at level 3 with a capability value of 3.32 , at this level DISDUKCAPIL Smart Bantul has implemented the Established Process while the expected conditions (to be) are at level 4 with a capability value of 4.5 which at this stage the Predictable Process has been applied.

The following is the determination of the APO12 capability level based on the results of the calculation of the capability value contained in each sub-process, as shown in the following Table 3:

Table 3. Determination of the APO12 capabilities

\begin{tabular}{|c|c|c|c|c|c|}
\hline \multirow{2}{*}{ No } & \multirow{2}{*}{$\begin{array}{c}\text { Sub- } \\
\text { Domain }\end{array}$} & \multicolumn{2}{|c|}{ Value } & \multicolumn{2}{c|}{ Capability } \\
\cline { 3 - 6 } & As is & To be & As is & To be \\
\hline 1 & APO12.01 & 2,91 & 4,26 & 3 & 4 \\
\hline 2 & APO12.02 & 3,31 & 4,43 & 3 & 4 \\
\hline 3 & APO12.03 & 3,26 & 4,4 & 3 & 4 \\
\hline 4 & APO12.04 & 3,32 & 4,36 & 3 & 4 \\
\hline 5 & APO12.05 & 3 & 4,65 & 3 & 5 \\
\hline
\end{tabular}

\begin{tabular}{|c|c|c|c|c|c|}
\hline 6 & APO12.06 & 3,15 & 4,35 & 3 & 4 \\
\hline \multicolumn{2}{|c|}{ AVG } & 3,21 & 4,41 & 3 & 4 \\
\hline
\end{tabular}

Based on the table above, it is known that in the APO12.01 sub-process the capability level is currently at level 3 with a capability value of 2.91 , in the APO12.02 sub-process the capability level is currently at level 3 with a capability value of 3.31 , in the APO12 sub-process. .03 capability level is currently at level 3 with a capability value of 3.26 , in the APO12.04 sub-process the capability level is currently at level 3 with a capability value of 3.32 , in the APO12.05 subprocess the capability level is currently at level 3 with a capability value of 3 , in the APO12.06 sub-process the current capability level is at level 3 with a capability value of 3.15 .

From the six sub-processes, it is known that the capability value for the APO12 process is 3.21. as shown in Figure 4:

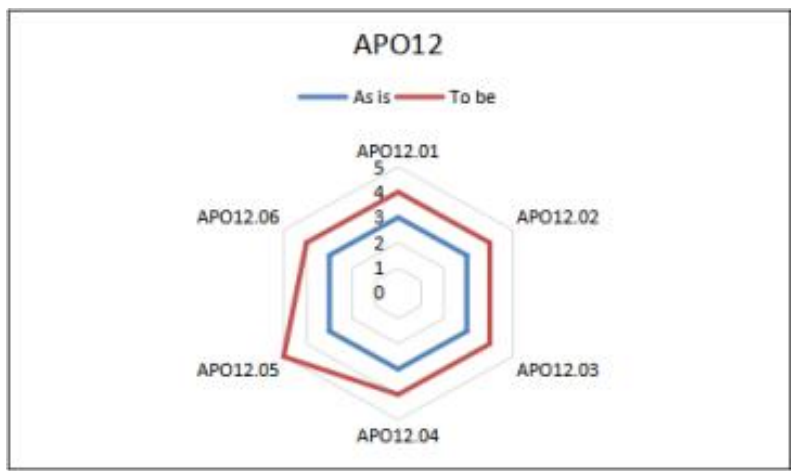

Figure4: Graph APO12 of Capability value

Based on the graph above, it is known that the condition (as is) in the APO12 (Manage Risk) process is at level 3 with a capability value of 3.21, at this level, DISDUKCAPIL Smart Bantul has implemented the Established Process while the expected conditions (to be) are at level 4 with a capability value of 4.41 which at this stage the has been applied Predictable Process.

Capabilty Level and Gap, At this stage discuss the results of the report and the results of the assessment from the previous stages. Here are described the gaps and gaps that exist in each process as well as recommendations to achieve the level of process capability expected by DISDUKCAPIL Smart Bantul, Population and Civil Registration Office of Bantul Regency. In addition, to complete the risk evaluation process, at this stage the researcher provides mitigation suggestions based on the risk assessment that the researcher has made, as shown in the following Table 4:

Table 4. Results Capability level recaptulation

\begin{tabular}{|c|c|c|c|}
\hline Name Process & As is & To be & Gap \\
\hline $\begin{array}{c}\text { EDM03 (Ensure Risk } \\
\text { Optimisation) }\end{array}$ & 3 & 4 & 1 \\
\hline APO12 (Manage Risk) & 3 & 4 & 1 \\
\hline
\end{tabular}

\subsection{Analysis Results The Capability Level}

Following are the results of assessment the capability level overall of the processes that have been assessed:

1. The capability level current(as is) in the EDM03 Ensure Risk Optimization process is at level 3 (Established Process) with a capability value of 3.39 while the 
capability level expected(to be) is at level 4 (Predictable Process) with a value of capability 4.47.

2. The capability level current(as is) in the APO12process Manage Risk is at level 3 (Established Process) with a capability value of 3.21 while the capability level expected(to be) is at level 4 (Predictable Process) with a capability value 4.41 .

Based on the data from the assessment results for each process, the authors then provide recommendations as suggestions for improvement to achieve the expected conditions for each process following COBIT 5 standards.

\subsection{Gaps and Recommendations of EDM03 process}

The value obtained in the assessment capability level is at level 3 with the expected conditions at level 4 , to achieve the capability level, these gaps and recommendations are obtained from the results of fulfilling the process that has been described at the stage Process Attribute Level so that the recommendations given are following the needs. current organization. Based on the table above, it is known that the capability indicator at level 1 has been achieved $100 \%$ in the category Fully Achieved so that further assessment is carried out at the following level. The capability indicator at level 2, 2 points must be met, namely Performance Management and Work Product Management, both of which have been achieved $100 \%$, the value of capability level 3 is still included in the category Largely Achieved with a percentage of 83.33\%. At level 32 points must be fulfilled, namely Process Definition and Process Deployment. In Process Definition, it has reached the level of $100 \%$ while in Process Deployment it has only reached $66.67 \%$. Before focusing on achieving at the expected level. DISDUKCAPIL Smart Bantul at Department of Population and Civil Registration of Bantul Regency is recommended to fill the gaps that exist at the previous levels. The following are the recommendations given by the researchers following the findings obtained at the stage of fulfilling the capability indicators, as shown in the following Table 5:

Table 5. Gaps and Recommendations EDM03

\begin{tabular}{|l|l|}
\hline \multicolumn{2}{|c|}{ EDM03 Ensure Risk Optiminations } \\
\hline \multicolumn{1}{|c|}{ Gaps } & \multicolumn{1}{|c|}{ Recomendatons } \\
\hline $\begin{array}{l}\text { Process of providing } \\
\text { resources and } \\
\text { information to support } \\
\text { risk optimization } \\
\text { performance has not } \\
\text { been identified. }\end{array}$ & $\begin{array}{l}\text { DISDUKCAPIL Smart Bantul } \\
\text { Population and Civil Registration } \\
\text { Office Bantul Regency is } \\
\text { recommended to provide } \\
\text { resources and information that } \\
\text { can support performance in } \\
\text { optimizing risk, one of which is } \\
\text { by providing training related to } \\
\text { the implementation of risk } \\
\text { optimization to improve HR } \\
\text { competencies. }\end{array}$ \\
\hline $\begin{array}{l}\text { No documents have } \\
\text { been found to identify } \\
\text { the proper } \\
\text { infrastructure } \\
\text { provision process. }\end{array}$ & $\begin{array}{l}\text { The Piak Division must identify } \\
\text { any infrastructure that can reduce } \\
\text { the possibility of carrying out } \\
\text { risks. Identify any infrastructure } \\
\text { that is vital and has a high-risk } \\
\text { value. }\end{array}$ \\
\hline
\end{tabular}

Based on the table above, it is known that 2 gaps must be met by DISDUKCAPIL Smart Bantul, the Population and Civil Registration Office of Bantul Regency to fulfill the requirements to level 3 in the EDM03 process. One of them is DISDUKCAPIL Smart Bantul. The Department of Population and Civil Registration of Bantul Regency is recommended to provide resources and information that can support performance in optimizing risk. One of them is by providing training related to the implementation of risk optimization to improve HR competencies. So that it can fill the gap that has not been identified in the provision of information resources. Before proceeding to the next level, DISDUKCAPIL Smart Bantul, the Bantul Regency Population, and Civil Registration Office is required to fulfill the improvements made at the previous level.

\subsection{Gaps and Recommendations of the APO12 process}

The value obtained in the assessment capability level is at level 3 with the expected conditions at level 4 , to achieve the capability level, these gaps and recommendations are obtained from the results of fulfilling the process that has been described at the stage Process Attribute Level so that the recommendations given are following the needs. current organization.Based on the table above, it is known that the capability indicator at level 1 reaches $86.67 \%$ even though it is included in the category Fully Achieved, but several Work Products must be met so that the assessment at level 1 reaches $100 \%$. In the assessment of capability indicators at level 2, 2 points must be met, namely Performance Management and Work Product Management, both of which have been achieved $100 \%$. At level 3 the value is capability level included in the category Largely Achieved with a percentage of $73.33 \%$ which has 2 points that must be fulfilled, namely Process Definition and Process Deployment. In Process Definition, it reaches $80 \%$ level while in Process Deployment it reaches $66.67 \%$. DISDUKCAPIL Smart Bantul Department of Population and Civil Registration of Bantul Regency is recommended to fill the gaps that exist at the previous levels. The following are recommendations given by researchers following the findings obtained at the stage of fulfilling the capability indicators, as shown in the following Table 6:

Table 6. Gaps and Recommendations APO12 EDM03 Ensure Risk Optiminations

\begin{tabular}{|c|c|}
\hline \multicolumn{2}{|c|}{ EDM03 Ensure Risk Optiminations } \\
\hline Gaps & Recomendatons \\
\hline $\begin{array}{l}\text { No document explains } \\
\text { the scope of risk } \\
\text { analysis. Especially } \\
\text { for the scope of IT. }\end{array}$ & $\begin{array}{l}\text { The PIAK Division of the Bantul } \\
\text { Regency Population and Civil } \\
\text { Registration Office is } \\
\text { recommended to determine the } \\
\text { scope of the risk analysis effort. } \\
\text { Which contains the boundaries of } \\
\text { the unit/agency about what } \\
\text { activities and strategies are. Who } \\
\text { owns the risk and its extent. It is } \\
\text { recommended to conduct a risk } \\
\text { analysis within the scope of the } \\
\text { PIAK Division of the Regency } \\
\text { Population and Civil Registration } \\
\text { Office. }\end{array}$ \\
\hline $\begin{array}{l}\text { There is no third-party } \\
\text { assessment result. }\end{array}$ & $\begin{array}{l}\text { It is recommended that } \\
\text { DISDUKCAPIL Smart Bantul } \\
\text { Department of Population and } \\
\text { Civil Registration of Bantul } \\
\text { Regency cooperates with third } \\
\text { parties in conducting risk } \\
\text { assessments to complete the }\end{array}$ \\
\hline
\end{tabular}




\begin{tabular}{|l|l|}
\hline & $\begin{array}{l}\text { internal audit. Obtain validity } \\
\text { from certified parties. }\end{array}$ \\
\hline $\begin{array}{l}\text { There has not been } \\
\text { found a suitable } \\
\text { method for risk } \\
\text { management. }\end{array}$ & $\begin{array}{l}\text { PIAK sector It is recommended to } \\
\text { find an appropriate method for the } \\
\text { risk management process. } \\
\text { Comparing methods, so that the } \\
\text { appropriate method can be found. }\end{array}$ \\
\hline $\begin{array}{l}\text { The process of } \\
\text { providing resources } \\
\text { and information to } \\
\text { support risk } \\
\text { optimization has not } \\
\text { been identified. }\end{array}$ & $\begin{array}{l}\text { In managing risk, the } \\
\text { DISDUKCAPIL Smart Bantul } \\
\text { Department of Population and } \\
\text { Civil Registration Bantul } \\
\text { Regency is recommended to } \\
\text { provide resources and information } \\
\text { that can support performance in } \\
\text { optimizing risk, one of which is } \\
\text { by providing training related to } \\
\text { the implementation risk } \\
\text { optimization to improve } \\
\text { HR(SDM) competence. }\end{array}$ \\
\hline $\begin{array}{l}\text { No documents have } \\
\text { been found to identify } \\
\text { the proper } \\
\text { infrastructure } \\
\text { provision process. }\end{array}$ & $\begin{array}{l}\text { PIAK sector must identify any } \\
\text { infrastructure related to reduce } \\
\text { the possibility of risk being } \\
\text { carried out. }\end{array}$ \\
\hline
\end{tabular}

Based on the table above, it is known that 5 gaps must be met by DISDUKCAPIL Smart Bantul, the Population and Civil Registration Office of Bantul Regency to fulfill the requirements to level 4 in the processAPO12.

\section{CONCLUSION}

Subsequent evaluating IT risk management at the Population and Civil Registration Office of Bantul Regency by knowing the level of ability to manage risks as well as analyzing and assessing existing risks using the framework, COBIT 5it can be concluded first. Based on the results of the calculation Capability Level current this (as is) PIAK field Office of Population and Civil Registration Bantul manage IT risk average is located at level 3(Established Process) and level capability the expected (to be) is at level 4 (Predictable Process) .and both magnitude The gap test result contained in the value capability current with the value capability expected is 1 . This can be seen from the absence of a corporate entity that specifically supervises and has accountability for doing so. So, some recommendations are given to fulfill it to the next level.

\section{REFERENCES}

[1] Arief, MH and Suprapto (2018). Evaluation of Information Technology Risk Management Using the COBIT 5 Framework (Case Study at Perum Jasa Tirta I Malang). Journal of Information Technology and Computer Science Development, 2(1), pp. 101-109.

[2] Septiadi BE, Kusnanto G and Supangat (2019), Maturity Level Analysis and Design of Information System Service Improvement for the Rectorate of the University of 17 August 1945 Surabaya (Case Study: University Information System Agency 17 August 1945 Surabaya). Convergence 1(15), January 2019.

[3] Agtika, AS, Mursityo, YT and Rachmadi, A. (2019). Evaluation of Information Technology Risk Management at the Planning, Research and Development Agency (Barenlitbang) Malang City Using Cobit 5 Domain EDM03 and APO12. Journal of Information Technology
Development and Computer Science, (5), pp. 42184225.

[4] Khairuna D, Wibowo S and Gamayanto I (2020). Evaluation of Information Technology Risk Management Using COBIT 5 Framework Based on Domain APO12 (Manage Risk) at the Head Office of BPR Agung Sejahtera. Journal of Information System, 5(1), May 2020: 18-26.

[5] Febriani F and Manuputty AD (2021), Evaluation of Governance to Improve Information Technology Management Performance Using the COBIT 5 Framework (Case Study of the Salatiga District Court Class IB). Journal of Informatics and Information Systems Engineering 7(1) p-ISSN : 2443-2210e-ISSN : 2443-2229.

[6] Fuad, M. N. (2020). Risk Management Assessment in UAD HR Information Technology Services Using the COBIT 5 Method.

[7] Firdaus, S. K. M. (2018). Evaluation of Information Technology Risk Management Using the COBIT 5 Framework

[8] Bungin, B. (2010). Quantitative Research Methods. Jakarta: Prenada Media group, Ed.

[9] Djojosoeharso, S. (1999). Principles of Risk Management and Insurance. Jakarta: SalembaEmpat.

[10] Fahmi, I. (2012). Production and Operations Management. Bandung: Alphabeta.

[11] Ibrahim, B. (2009). Total Quality Management: A Guide to Facing Global Competition. Jakarta: PT. Main Library Gramedia.

[12] ISACA. (2012). COBIT 5: A Business Framework for the Governance and Management of Enterprise IT. Rolling Meadows, ISACA.

[13] ISACA. (2013). COBIT 5 Process Assessment Model. USA: IT Governance Institute.

[14] Arikunto, S. (2010). Research Procedure A Practical Approach. Jakarta: RinekaCipta.

[15] Seojadi (1997:107), Modern Management Analysis. Jakarta: Earth Literacy.

[16] Khairuna, D., Wibowo, S. and Gamayanto, I. (2020). Evaluation of Information Technology Risk Management Using COBIT 5 Framework Based on Domain APO12 (Manage Risk) at the Head Office of BPR Agung Sejahtera. 5(1), pp. 18-26.

[17] Megawati and Syntia, A. (2018). Evaluation of Information Technology Risk Management Using the COBIT 5.0 Framework. Scientific Journal of Information Systems Engineering and Management, 4(2), pp. 118122.

[18] Putri, CU (2017). Risk Assessment of Information Technology Processes Based on the Cobit 5 Framework at the Helpdesk, Sub-directorate of Information Technology and Systems Services, Directorate of Information Technology and Systems Development (DPTSI) SepuluhNopember Institute of Technology. 241.

[19] Putri, YI, Suprapto and Herlambang, AD (2018). Assessment of the Capability of Implementing Information Technology Risk Management Using the 
COBIT 5 Framework (Study on PDAM Malang City, East Java). Journal of Information Technology and Computer Science Development, 2(11), pp. 4855-4862.

[20] Pendidik.co.id., 2021. Definition of Service According to Experts. Found on Wednesday 7 April 2021, from.

[21] Stewart, J., Chapple, M., \& Gibson, D. (2015). CISSP(ISC) 2 Certified Information Systems Security Professional Official Study Guide. 7th Edition, Wiley.

[22] Yep, P. 2017. Corporate Risk Management. Jakarta: Growing Publishing.

[23] Kusaeri and Suprananto, Measurement and Assessment of Education, (Yogyakarta: Grahallmu 2012) page 17.

[24] M. NgalimPurwanto, Teaching Evaluation Principles and Techniques, (Bandung: Rosdakarya Youth 2010) page. 3.
[25] Andriani, Y. P. (2021). Risk Assessment of Monitoring Services using COBIT 5 Framework.

[26] Saputra, C. D. (2021). Analysis of Risk Assessment on Integrated Information System using COBIT 5 Framework.

[27] Indriyanto. (2021). Analysis of Risk Assessment on Stock System Services using COBIT 5 Framework.

[28] Maghribi, A. N. (2021). Analysis Risk Assessment on Village Information System using OCTAVE Allegro Framework.

[29] Ningsih, N. F. (2021). Risk Assessment Analysis on Library Information System using OCTAVE Allegro Framework 